Reviews

story is about how the fight for community control and nuclear power in Wasco, in California's Central Valley, northwest of Bakersfield, marked the transformation of the movement into the voice of a general public sentiment against nuclear power.

\title{
The Political Ecology of Bananas: Contract Farming, Peasants, and Agrarian Change in the Eastern Caribbean. By Lawrence S. Grossman. Chapel Hill: University of North Carolina Press (1998) xviii, 268 pp.
}

\section{Reviewed by Mark Moberg, Department of Sociology and Anthropology, University of South Alabama}

Until the early 1980s, the persistence of "peasants" in the commercial agricultural sectors of postcolonial societies prompted acrimonious debate among political economists. Are small-scale farmers who rely on household labor destined to extinction in competition with larger capitalist farms, as Marx originally argued? Are they a source of "spontaneous capitalism," prone to social differentiation into proletarians and commercial farmers, as Lenin claimed? Conversely, are they able to out-compete commercial farms due to their famed capacity for "self-exploitation," as Chayanov had contended? Finally, many neo-Marxists, such as Deere and De Janvry, challenged the very terms of the debate by noting that what appeared to be rural cultivators were in fact "disguised" or semi-proletarians. As De Janvry (1981) observed in the most compelling contribution to the exchange, the peasant question is fraught with practical and political implications that far exceed the semantics of the debate. Indeed, the exchange may have been so exceptionally fervent because it recapitulated Soviet policy debates that ended in collectivization and the persecution of scholars and policy-makers who favored a smallholder-based rural economy.

If the peasant studies debate of the 1970s and 80s vanished into the post-structuralist tide that later overtook the social sciences, the issues it raised, like the peasantry itself, have stubbornly refused to go away. Recent decades have actually witnessed an expansion of peasant involvement in commercial agriculture in much of the developing world, seemingly in defiance of political economists' predictions of a "disappearing" peasantry or one that is consigned to staple production. Are such trends a vindication of Chayanov and final refutation of Marxist political economy? In The Political Ecology of Bananas, Lawrence Grossman demonstrates that peasant persistence in export production is related less to the resilience of household economies than to the interests of the multinational firms that market peasant produce in the developed world. Grossman's book is one of several recent studies examining a significant structural change occurring in tropical agriculture over recent decades: the shift from vertically-integrated plantation production under direct corporate control to various forms of sub-contracting, often involving household-based units of production. Such arrangements have been initiated by most of the corporations that dominate world markets in crops such as bananas, coffee, cacao, citrus and sugar, and are now commonplace in Africa, Asia, Latin America, as well as the Eastern Caribbean context that Grossman documents.

Unlike the earlier peasant studies literature, which remained at the levels of household and national economies, recent analyses have situated contract farming within the changing framework 


\section{Reviews}

(or "mode of regulation") governing global capital accumulation since the 1970s. As global capitalism turned toward a post-Fordist mode of regulation, corporations adopted forms of "flexible accumulation" that permitted them to quickly alter product lines, access niche markets, and otherwise respond to volatile consumer tastes. Corporations have increasingly rid themselves of fixed costs (such as land and production facilities) and many members of their permanent workforces, shifting instead to out-sourcing arrangements for many of their products. Outsourcing has enabled manufacturers to slash payrolls and benefits, domesticate their remaining permanent workers, and institute the just-in-time inventory practices essential to servicing rapidly changing consumer demands. In this endless process of "creative destruction," contemporary capitalism has once again confounded political economists by resurrecting forms of production once thought to be moribund, such as industrial homework and peasant-based commodity production.

The Political Ecology of Bananas situates the farming community of Restin Hill, St. Vincent, within the constraints of the global banana trade as represented locally by Geest, the Dutch multinational that exports the island's bananas. Without directly alluding to the earlier peasant studies debate, Grossman demonstrates that corporations such as Geest may actually prefer subcontracting arrangements with peasants for the same qualities once extolled by Chayanov and noted in the neo-Marxist literature. Peasants may be willing to work under conditions that are unprofitable for larger entities due to their ability to generate some of their own food needs (the "subsidy to capital" noted by de Janvry and other political economists), as well as their capacity for "self-exploitation" from their reliance on unpaid household labor. Yet another reason that multinational corporations may prefer peasants, rather than large landowners, as sources of agricultural commodities is their comparative lack of power and inability to influence the state vis ^vis foreign capital.

Much of Grossman's analysis is given over to the appropriateness of regulation theory (specifically, its characterization of the shift to post-Fordist flexible accumulation) to understanding the growth of contract farming. Competition between multinationals for markets and their corresponding need to reduce costs under flexible accumulation compel them to shift away from costly plantation-based operations to contract farming. Similarly, to compete for consumers in the developed countries the banana companies have emphasized product appearance, in turn forcing their peasant suppliers to comply with steadily increasing standards of fruit quality. "Blemishes that were once ignored by customers ten or twenty years ago," Grossman notes, "make produce unsalable today" (p. 196) His analysis demonstrates how this seemingly benign trend has entailed significant, even devastating, consequences for health, labor and the environment in peasant communities such as Restin Hill. Peasants have had to endure a succession of ever more complicated company-imposed processing and packing procedures that have dramatically increased demands for their labor and expertise. Corporate expectations for fruit quality have also forced farmers to rely on a widening array of hazardous agro-chemicals, many of which are deployed in high doses and with little or no protective clothing.

As in other banana industries based on contract farming (Moberg 1997), Geest requires that its suppliers employ specific production procedures and inputs, and assigns prices to their fruit based on non-negotiable scoring criteria and procedures. The state, in the form of a statutory corporation (the St. Vincent Banana Growers Association), acts as an intermediary between individual growers and foreign capital. Because it employs extension agents that oversee the implementation of techniques and inputs mandated by Geest, it is the SVBGA rather than the corporation that often draws the ire of small farmers forced to comply with seemingly arbitrary production requirements. Other researchers (Clapp 1994; Watts 1994) have inferred from such coercive practices that the peasants involved in sub-contracting schemes are actually "disguised wage laborers" whose control over the production process is illusory. Similarly, regulation theorists have claimed that contract farming entails a de-skilling of labor comparable to that found in Fordist industry as a means of enhancing corporate control of labor and profit generation. Grossman demonstrates that both concepts are simplistic if not entirely inapplicable to 
Reviews

banana growers on St. Vincent. Paralleling Scott's (1985) concept of "everyday forms of peasant resistance," residents of Restin Hill surreptitiously divert company-supplied inputs to their own food crops or sell their produce to alternative buyers. As for the claim that contract farming imposes a series of simplified de-skilled operations on peasant producers, Grossman shows that rising standards for fruit quality have instead astronomically increased demands made of peasants in terms of labor and technical expertise since the 1960s. The most telling indication of this process is the size of the technical manual provided to farmers by extension agents, which increased from 19 pages in length in 1966 to 107 pages by 1993 !

In addition to assessing applications of regulation theory to contract farming, The Political Ecology of Bananas analyzes the impact of banana farming on food production and environmental quality on St. Vincent. Here his employment of a political ecology framework draws connections between the global and local systems, and human and natural environments, that are too often overlooked in more narrowly ecological or political economic perspectives. In contrast to arguments that any land or labor directed toward export production in peasant communities necessarily reduces their commitment to staple foods, the relationship between these activities in Restin Hill is more complex than might be assumed. Banana production does tend to limit food crop cultivation, but only indirectly as farmers have found that their export crops, together with the intensive demands for their processing and packing, are less likely to be stolen by neighbors than are food crops (p. 186). Similarly, Grossman reveals the unanticipated consequences of corporate requirements of input use on the environment and food production. The adoption of organochlorine insecticides and herbicides in the 1960s has since fueled a vicious and ultimately futile technological treadmill in which pests develop resistance to existing treatments, forcing peasants to apply new chemicals in increasing doses. Because of the proliferation of chemicalresistant pests on local farms, peasants now routinely spray chemicals intended for bananas on their food crops as well, raising uncertainties about their eventual health effects.

Many recent analyses of globalization risk the same limitation that world systems approaches often encountered in the $1970 \mathrm{~s}$ and $80 \mathrm{~s}$, one that anthropologist June Nash summarized as "the problem of the passive periphery" (1981: 398) Political economists have tended to portray postcolonial societies as "passive" entities whose characteristics are determined by their insertion into the global system. The residents of Restin Hill confront imperious demands by the banana multinational that purchases their fruit, blame extension agents rather than Geest for their difficulties and low prices, and mix terrifying "chemical cocktails" for use in their farms. Are they, then, another illustration of peasants haplessly ensnared in political economic structures beyond their control? To his credit, Grossman shows that the new sub-contracting, born of the incessant grasp for profit under flexible accumulation, also offers its victims unexpected spaces for maneuver and resistance. Neither capital nor the state can entirely regiment the production process, control the utilization of inputs on farms, or even compel peasants to grow bananas for export in the first place. This careful, insightful, frequently brilliant analysis of contract farming reveals the constraints and opportunities of the contemporary global system, and restores some measure of agency to the peasant communities that are involved in it.

\section{References Cited:}

Clapp, Roger.

1994. "The Moral Economy of the Contract." In Peter D. Little and Michael J. Watts, eds., Living under Contract: Contract Farming and Agrarian Transformation in SubSaharan Africa. Madison: University of Wisconsin Press. pp. 78-94.

De Janvry, Alain.

1981. The Agrarian Question and Reformism in Latin America. Baltimore: Johns Hopkins University Press.

Journal of Political Ecology

Vol. 61999 
Reviews

Moberg, Mark.

1997. Myths of Ethnicity and Nation: Immigration, Work, and Identity in the Belize

Banana Industry. Knoxville: University of Tennessee Press.

Nash, June.

1981. "Ethnographic Aspects of the World Capitalist System." Annual Review of Anthropology 10: 393-424.

Scott, James.

1985. Weapons of the Weak: Everyday Forms of Peasant Resistance. New Haven: Yale University Press.

Watts, Michael J..

1994. "Life under Contract: Contract Farming, Agrarian Restructuring, and Flexible

Accumulation." In Peter D. Little and Michael J. Watts, eds., Living under Contract: Contract Farming and Agrarian Transformation in Sub-Saharan Africa. Madison: University of Wisconsin Press. pp. 21-77.

\section{Tracing the Veins: Of Copper, Culture and Community from Butte to Chuquicamata. by Janet L. Finn. Berkeley: University of California Press (1998) 327 pp.}

\section{Reviewed by Judy Root Aulette, Department of Sociology, University of North Carolina at Charlotte.}

Like the tale of those other two cities, Janet Finn's book about Butte, Montana and Chuquicamata, Chile is a complex story with surprising twists in a long history of wars, revolutions, betrayal and the human spirit. Unlike Dickens, Finn does not tie up all the loose ends at the conclusion. An account of real life rather than a novel, the story that unfolds is still unfinished and has opened up as many questions as it has answered.

Finn started her work with a relatively direct question about how a strike in the 1960s had been experienced by the copper mining community in Butte. The people she began to interview, however, had difficulty explaining that event in the 1960s without putting it into the historical context of the Twentieth Century. As Finn began to do documentary research on this history, she discovered that the story of Butte could not be told without exploring the 'sister city' of Chuquicamata, Chile. She then traveled to Chile to investigate the history of that mining town and embarked on a three-year journey, traveling back and forth between the two sites.

The book provides an intricate ethnographic description that includes field notes, interviews, and documents; spans two languages, two nations, and one hundred years of history; and reports a myriad of voices from dictators to media people, union leaders, men miners and community women. 